\title{
Thumb and index finger macrodactyly with first carpometacarpal and scaphotrapezotrapezoidal joints fusion: inevitable consequence?
}

\author{
Karthikeyan P Iyengar, ${ }^{1}$ Hosam E Matar, ${ }^{2}$ Khushroo Suraliwala ${ }^{1}$
}

${ }^{1}$ Department of Trauma and Orthopaedics, Southport and Ormskirk Hospital NHS Trust, Southport, Merseyside, UK ${ }^{2}$ Department of Trauma and Orthopaedics, Leighton Hospital, Crewe, Cheshire, UK

\section{Correspondence to} Hosam E Matar, hematar@doctors.org.uk

Accepted 28 November 2016

\section{DESCRIPTION}

Macrodactyly is a descriptive term used for a rare anomaly of disproportionately large digit noted at birth or that develops within the first years of life. The soft tissue and skeletal elements are diffusely enlarged in the affected digit or digits. ${ }^{1}{ }^{2}$ Most cases appear sporadically without evidence of inheritance. The anomaly is generally unilateral and may affect more than one digit, when the thumb involved, it assumes an abducted and extended attitude. The bony growth continues until

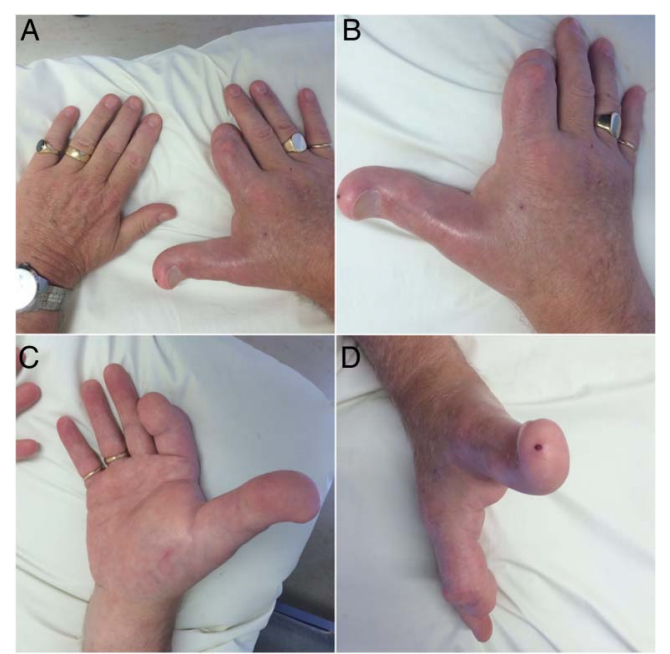

Figure 1 Clinical photograph of the right hand of a man aged 68 years with thumb and index finger macrodactyly. He had terminalisation of his index finger's distal phalanx as a child.

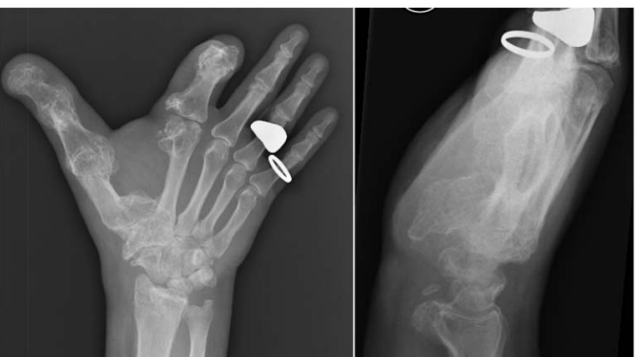

To cite: lyengar $K P$, Matar HE, Suraliwala K. BMJ Case Rep Published online: [please include Day Month Year] doi:10.1136/bcr-2016218043
CrossMark

Figure 2 Posterioanterior and lateral plain radiographs of the right hand and wrist demonstrating large hypertrophied exostosis with severe degenerative changes and ankylosis at the metacarpophalangeal and interphalangeal joints of the thumb as well as the first carpometacarpal and scaphotrapezotrapezoidal joints. physeal closure; however, soft tissue enlargement may continue into adulthood. The enlarged digits stiffen during growth, which further limits function as the enlarged digit or digits often obstruct grasp and pinch. Patients are usually initially evaluated in childhood with indications for surgery based on functional and aesthetic grounds. Macrodactyly's management is very challenging due to its progressive and diffuse nature preventing complete correction to normal. Surgical options are either to limit ongoing growth, reduce the size of the digit or correct the deviation, as well as amputation. ${ }^{13}$

We present very interesting clinical photographs and plain radiographs of a man aged 68 years with right hand macrodactyly of the thumb and index finger which we believe is the longest follow-up of macrodactyly to be reported in the literature. An attempt to correct his index finger deformity, during childhood, resulted in gangrene to the tip and surgical terminalisation of the index finger was undertaken (figure 1). Despite this, he has maintained full use of this dominant hand. He recently sustained a closed traumatic injury to his right hand and plain radiographs were obtained to rule out any fractures (figures 2 and 3). These demonstrate advanced degenerative changes and fusion across the base of the thumb and carpus and he retained his preinjury function with simple conservative measures.

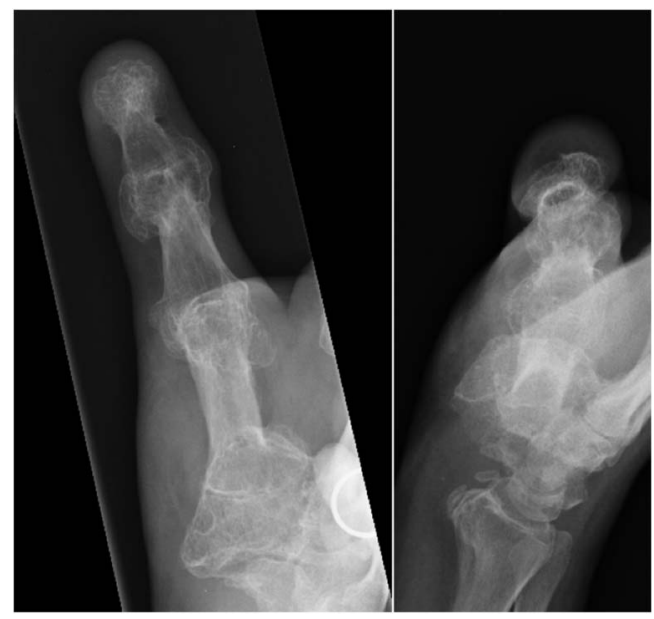

Figure 3 Posterioanterior and lateral plain radiographs of the right thumb with severe degenerative changes, osteophytes and ankylosis at the metacarpophalangeal and interphalangeal joints of the thumb. 


\section{Learning points}

- The most common form of macrodactyly is sporadic isolated anomaly with unknown aetiology.

- Most cases of macrodactyly occur in a single digit or in a region innervated by a single nerve (nerve territory-oriented macrodactyly).

- Macrodactyly is difficult to treat. Its progressive and diffuse nature prevents complete correction, despite multiple surgeries to remove the extraneous tissues, the end result may be unsatisfactory.
Contributors KPI managed the patient, contributed to manuscript. HEM contributed to manuscript. KS managed the patient, contributed to manuscript.

Competing interests None declared.

Patient consent Obtained.

Provenance and peer review Not commissioned; externally peer reviewed.

\section{REFERENCES}

1 Akinci M, Ay S, Ercetin O. Surgical treatment of macrodactyly in older children and adults. J Hand Surg Am 2004;29:1010-19.

2 Flatt A. The care of congenital hand anomalies. St Louis: Quality Medical Publishing, 1994.

3 Tsuge K. Treatment of macrodactyly. J Hand Surg Am 1985;10(Pt 2):968-9.

Copyright 2017 BMJ Publishing Group. All rights reserved. For permission to reuse any of this content visit http://group.bmj.com/group/rights-licensing/permissions.

BMJ Case Report Fellows may re-use this article for personal use and teaching without any further permission.

Become a Fellow of BMJ Case Reports today and you can:

- Submit as many cases as you like

- Enjoy fast sympathetic peer review and rapid publication of accepted articles

- Access all the published articles

- Re-use any of the published material for personal use and teaching without further permission

For information on Institutional Fellowships contact consortiasales@bmjgroup.com

Visit casereports.bmj.com for more articles like this and to become a Fellow 